\title{
Supratentorial Ectopic Ependymoma
}

\author{
Olivier Vernet, Jean-Pierre Farmer, Kathleen Meagher-Villemure and José L. Montes
}

\begin{abstract}
Background: Ependymomas usually arise from the ventricular surface. Methods: We report an 11-year-old female who presented with a supratentorial ectopic ependymoma. Results: The patient presented with a two-month-history of progressive headache, nausea and vomiting. Examination revealed papilledema, horizontal nystagmus, diplopia on upward gaze, and right pronator drift. CT scan showed an enhancing left precentral subcortical lesion measuring $3 \mathrm{~cm}$ in diameter with associated edema and mass effect. Its medial border was located $3 \mathrm{~cm}$ from the ependymal surface of the ventricle. A firm tumour was dissected from the centrum semiovale white matter, and removed in toto as confirmed on MRI. Pathological examination revealed histological, immuno-histochemical and electron microscopic features consistent with an ependymoma. Spine MRI and bone marrow aspirate, as well as lumbar puncture of cytology failed to show any dissemination. Conclusion: From the literature review, this represents an exceptional ependymoma located at the distance from the ventricular system or cisterns. Different pathogenic alternatives are discussed.
\end{abstract}

\begin{abstract}
RÉSUMÉ: Épendymome ectopique supratentoriel. Objectif: Les épendymomes sont généralement issus de la surface ventriculaire. Méthode: Nous rapportons d'une fillette de 11 ans présentant un épendymome supratentoriel ectopique. Résultats: Cette patiente souffrait depuis 2 mois de céphalées progressives, de nausées et de vomissements. A l'examen neurologique, on relevait un oedème papillaire, un nystagmus horizontal, une diplopie pour le regard vers le haut et une pronation de la main droite à l'épreuve des bras tendus. Le CT scan montrait une lésion de $3 \mathrm{cms}$ de diamètre, sous-corticale, précentrale, captant le contraste, entourée d'oedème avec effet de masse. Sa partie médiane était située à $3 \mathrm{cms}$ du ventricule. Cette tumeur ferme a été totalement extirpée du centre semi-ovale tel que confirmé à l'IRM post-opératoire. Le diagnostic retenu après examen histologique, immuno-histochimique et après microscopie électronique fut celui d'épendymome. Une IRM spinale, un examen de moelle osseuse et une ponction lombaire n'ont pas montré de dissémination tumorale. Conclusion: Après revue de la littérature, ce cas paraît exceptionnel par sa localisation à distance du système ventriculaire ou cisternal. Différentes alternatives pathogéniques sont discutées.
\end{abstract}

Can. J. Neurol. Sci. 1995; 22: 316-319

Ependymomas are rare tumours arising from the cells lining the ventricular system and the central canal of the spinal cord. They account for $1.2 \%$ to $6 \%$ of primary intracranial neoplasms $^{1-4}$ and $24 \%$ of the intraspinal tumours. ${ }^{5}$ Intracranial ependymomas are preferentially encountered in children in whom they represent up to $12 \%$ of all brain tumours, ${ }^{3.5-9}$ whereas intraspinal ependymomas occur essentially in young adults. ${ }^{2.5 .10 .11}$ Approximately two-thirds of cerebral ependymomas are infratentorial and most of them arise within the fourth ventricle. ${ }^{1.4-11}$ We present the unusual case of supratentorial ependymoma of the frontal lobe located within the parenchymal substance and exhibiting no continuity with the ventricular system or cisterns.

\section{Case Report}

This 11-year-old female presented with a two-month-history of nausea and morning vomiting. Over the two weeks prior to admission, she experienced headache and intermittent diplopia. Neurological examination was remarkable for an alert patient complaining of violent diffuse headache. She exhibited bilateral papilledema, spontaneous horizontal nystagmus, diplopia on upward gaze, and right pronator drift.

Laboratory investigations were normal. A CT scan demonstrated a 3 $\mathrm{cm}$ diameter mass lesion in the left frontal region. It was isodense on the plain CT scan and had marked peripheral contrast enhancement on the infused study. The mass appeared contiguous with the frontal bone on several sections. There was a very large amount of associated edema with slight shift of the midline to the right as well as dilatation of the contralateral temporal horn. The basal cisterns were largely obliterated. No communication between the lesion and the ventricular system was identified on careful examination of the main images of the CT scan (Figure 1).

Given the precarious clinical status of the patient, an emergency left fronto-parietal osteoplastic craniotomy was performed. The cortical surface was surprisingly grossly unremarkable. An echogenic firm mass, located a few millimetres deep to the surface, was dissected from the centrum semiovale. The lesion was well delineated from the surrounding edematous brain and was not excessively vascularized. There was no gross connection with the left lateral ventricle and the subarachnoid space. The tumour was removed in toto.

From the Departments of Neurosurgery (O.V., J-P.F., J.L.M.) and Pathology (K.M-V.), The Montreal Children's Hospital, McGill University, Montreal, Quebec.

RECEIVED JANUARY 19, 1995. ACCEPTED IN FINAL FORM MAY 30, 1995.

Reprint requests to: Dr. Jean-Pierre Farmer, Service of Neurosurgery, The Montreal Children's Hospital, 2300 Tupper Street, Room C-811, Montreal, Quebec, Canada H3H 1 P3 

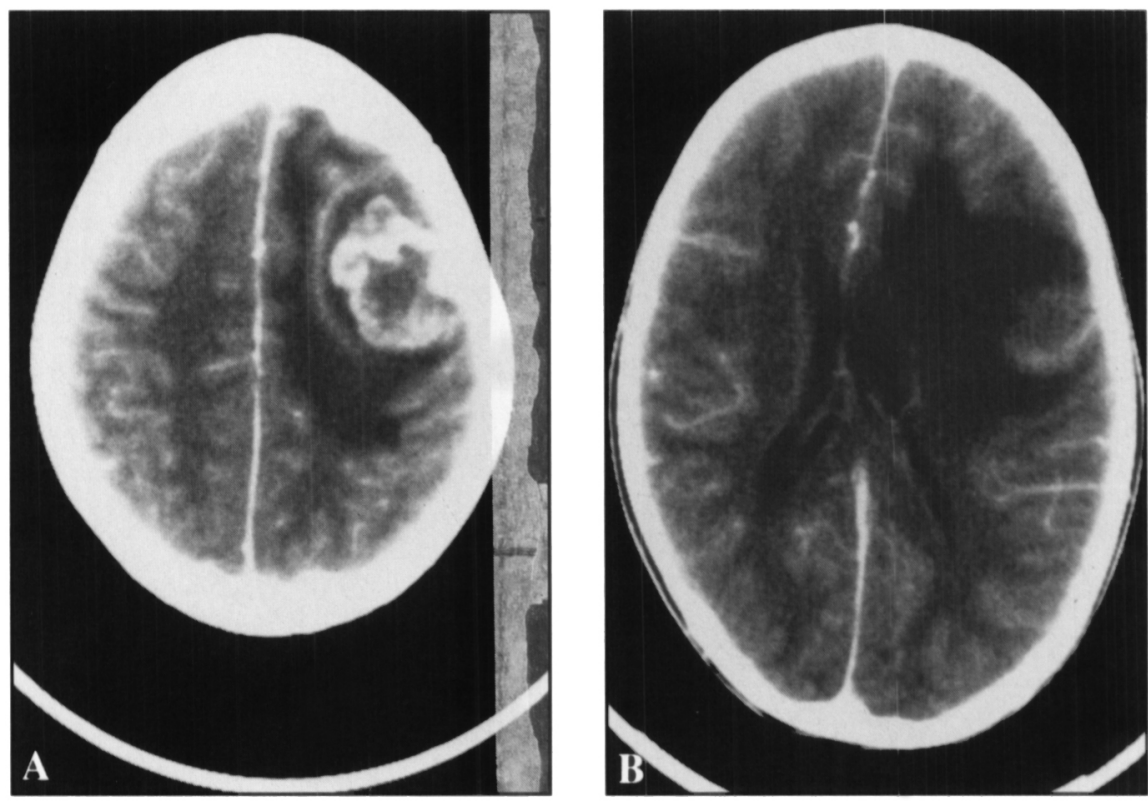

Figure 1: Contrast-enhanced computerized tomography scan demonstrating a $3 \mathrm{~cm}$ diameter contrast-enhancing lesion in the left frontal region with large amount of associated edema $(\boldsymbol{A})$. There is no continuity between the lesion and the ventricular system $(\boldsymbol{B})$.

On gross inspection, the surgical specimen was composed of multiple fragments of hemorrhagic, white and grey soft tissue. Histological sections revealed that the lesion was very cellular and well vascularized. There were numerous large pseudorosette formations. The cells of these formations had their nuclei aligned around central vessel, with the eosinophilic cytoplasmic processes directed toward the vessel. The nuclei were quite uniformally oval with mild polymorphism and hyperchromaticity. Rare mitotic figures and true rosettes were seen. Large areas of necrosis were visualized in the tumour (Figure 2). Within the tumour, immuno-chemistry showed that neuron-specific enolase (NSE) was equivocal, synaptophysin was negative, and glial fibrillary acidic protein (GFAP) was positive in some tumour cells. Cytokeratin and epithelial membrane antigen (EMA) had negative reactivity. Ultrastructural study was done on a fragment of tumour fixed in gluteraldehyde. It showed the tumour cells to be made of large nuclei, often cleaved, with thin chromatin at the periphery. The cytoplasm contained numerous organelles, rough endoplasmic reticulum, mitochondriae, lysosomes, numerous microfilaments, long cytoplasmic processes filled with microfilaments and microtubules. There were some cells with centrioles, others with immature ciliary bodies, and numerous very long junctional complexes at the apex of cells ("zipper-like" junctions). Some cells surrounded a lumen and projected microvillosities in the lumen (Figure 3). These findings suggested a Grade II-IV ependymoma according to the WHO revised classification of 1993. ${ }^{12}$ Necrosis is not an infrequent finding in ependymoma and is not necessarily indicative of a more aggressive behaviour. ${ }^{13}$

The post-operative course was uneventful with complete resolution of symptoms present on admission. Papilledema, however, persisted during the hospitalization. Post-operative CT scan and MRI confirmed the complete tumour resection. Further work-up, including spine MRI, bone marrow aspirate as well as lumbar puncture for cytology failed to show any dissemination.

\section{Discussion}

The radiological differential diagnosis of such a lesion included a high grade glioma, a primitive neuro-ectodermal tumour, a metastasis, as well as an atypical meningioma, given the superficial extension noted on several sections of the CT scan. A hemangioblastoma, as well as a ganglioglioma, ${ }^{14}$ were also part of the differential diagnosis.

This case involves a supratentorial ependymoma of unusual location and, in particular, without attachment to the ventricular system. Our review of the literature reveals that in older series, the occurrence of supratentorial ependymomas, without any visible attachment to the ventricular system, seemed to be a frequent feature, reported in more than one-half of the cases. ${ }^{2,6.10,11}$ However, these studies were all conducted during the pre-CT

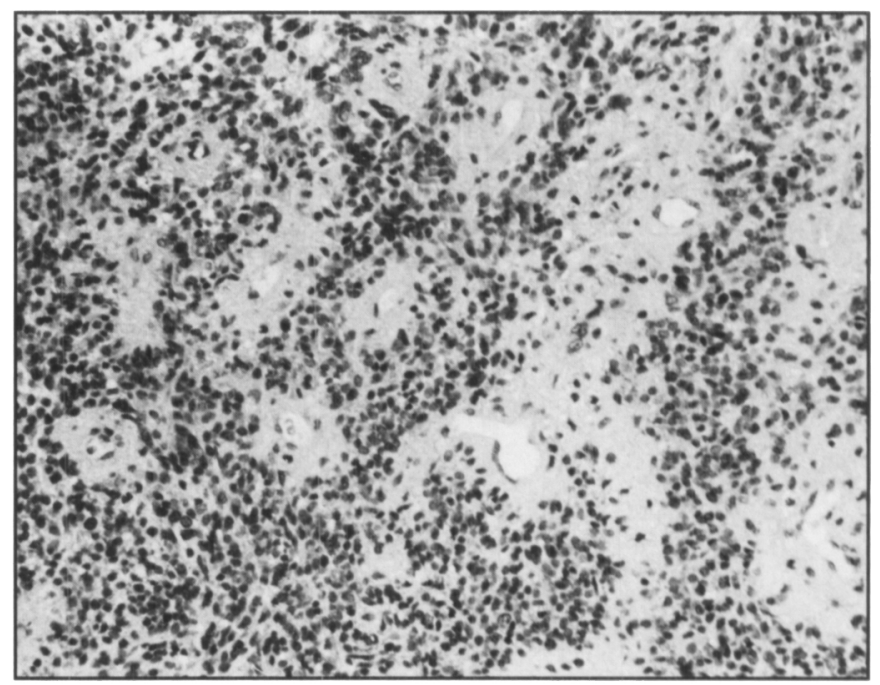

Figure 2: Photomicrograph showing cellular proliferation in pseudo rosette arrangement (HPS, 20X). 


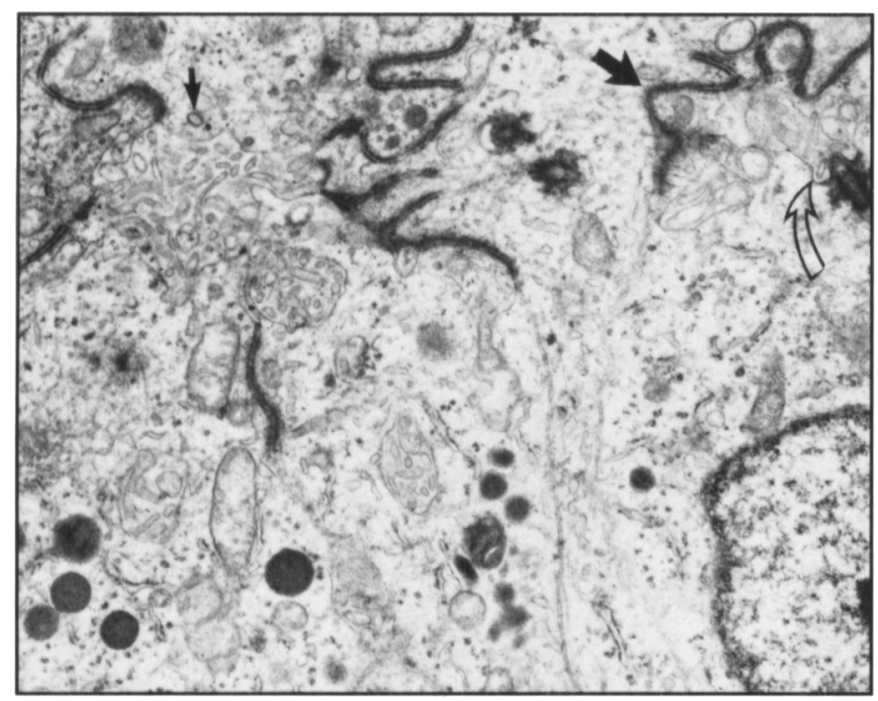

Figure 3: Ultrastructure study with tumour cells showing well-developed long "zipper-like" junction (large arrow, apical microvillosities (small arrow), and ciliary body (curved arrow).

scan era and, the only means to evaluate the relation of the supratentorial mass lesion with the ventricular system at this time, was by plain skull $x$-rays, ventriculography, pneumoencephalography, angiography, or at surgery. Consequently, it is difficult to accurately comment upon the proximity of these supratentorial lesions to the normal ependymal lining. To our knowledge, there is only one recently reported case of supratentorial ectopic ependymoma investigated by MRI. ${ }^{15}$ In this report, the ependymoma arose from the trigeminal nerve.

In the posterior fossa, the occurrence of ependymomas extending outside the fourth ventricle into the subarachnoid space or the cisterna magna through the foramen of Luschka and Magendie is well known. ${ }^{4,11,16,17}$ These tumours, labelled "plastic ependymomas" by Courville and Broussalian, ${ }^{16}$ however, always have some continuity with the ventricular ependymal lining and, therefore, cannot be considered as true ectopic ependymomas. So far, to our knowledge, there was only one reported case of an infratentorial ectopic ependymoma arising from the cerebellar cortical surface. ${ }^{18}$

Equally rare are the extraspinal ependymomas. They were described in the sacrococcygeal or in the cervicothoracic regions, and were considered to arise from heterotopic ependymal cell rests or coccygeal medullary vestiges. ${ }^{19-22}$

The pathogenesis of this supratentorial ectopic ependymoma is unclear. We envisage three possibilities. First, the tumour could have developed from an ependymal cyst. Intraparenchymal or subarachnoid ependymal cysts have abundantly been reported in the literature. ${ }^{23.28}$ They were thought to develop as an outpouching from ventricles or to derive from heterotopic ependymal nests resulting from migration disorders from the germinal matrix. ${ }^{24.26 .27}$ In the present case, the ventricular contour was intact and the closest margin of the tumour was estimated to be $3 \mathrm{~cm}$ away from the ventricle. Secondary development of an ependymoma from an outpouched ependymal cell lining thus seems improbable here. Another possible pathogenic hypothesis would be to consider that the tumour described here would, in fact, represent a primitive neuroectodermal tumour which would have differentiated extensively along the ependymal lineage.
However, the uniform and differentiated histological features of this tumour, and the relatively old age of the patient, make this possibility unlikely. Finally, a more tempting hypothesis is to postulate that the lesion described here might be the result of a neoplastic growth within an ectopic ependymal cell of the frontal cortex or adjacent leptomeninge ${ }^{28.29}$ and, therefore, at least in part, a consequence of a migrational error.

In conclusion, this report points out that although exceptional in this location, ependymoma has to be included in the radiological differential diagnosis of a contrast-enhancing parenchymal mass lesion even in the absence of any visible connection with the ventricular system.

\section{ACKNOWLEDGeMENTS}

Dr. Olivier Vernet is Fellow of "Le Fonds de perfectionnement du CHUV", "La Société Académique Vaudoise", "Le Fonds Decker", and "La Société SICPA SA" - Lausanne, Switzerland.

\section{REFERENCES}

1. Barone BM, Elvidge AR. Ependymomas. A clinical survey. J. Neurosurg 1970; 33: 428-438.

2. Mørk SJ, Løken AC. Ependymomas. A follow-up study of 101 cases. Cancer 1977; 40: 907-915.

3. Russel DS, Rubinstein LJ. Pathology of Tumours of the Nervous system, 5th Edition. London: Williams \& Wilkins, 1989: 187-206.

4. Svein HJ, Mabon RF, Kernohan JW, Craig W. Ependymoma of the brain: pathological aspects. Neurology 1953; 3: 1-15.

5. Dohrmann GJ, Farwell JR, Flannery JT. Ependymomas and ependymoblastomas in children. J Neurosurg 1976; 45: 273-283.

6. Coulon RA, Till K. Intracranial ependymomas in children. A review of 43 cases. Child's Brain 1977; 3: 154-168.

7. Goldwein JW, Leahy JM, Packer RJ, et al. Intracranial ependymomas in children. Int J Radiation Oncology Biol Phys 1990; 19: 1497-1502.

8. Liu HM, Boggs J, Kidd J. Ependymomas of childhood. I. Histological survey and clinicopathological correlation. Child's Brain 1976: 2: 92-110.

9. Nazar GB, Hoffman HJ, Becker LE, et al. Infratentorial ependymomas in childhood: prognostic factors and treatment. $J$ Neurosurg 1990; 72: 408-417.

10. Fokes EC, Earle KM. Ependymomas: clinical and pathological aspects. J Neurosurg 1969; 30: 585-594.

11. Ringertz N, Reymond A. Ependymomas and choroid plexus papillomas. J Neuropathol Exp Neurol 1949; 8: 355-380.

12. Kleihyes P, Burger PC, Scheithauer BW. Histological Typing of Tumours of the Central Nervous System. 2nd Edition Berlin, Heidelberg, New York, London, Paris: Springer Verlag, 1993: 17-18.

13. Burger PC, Scheithauer BW. Atlas of tumour pathology: tumours of the central nervous system. Armed Force Institute of Pathology, Washington DC. 1994:127.

14. Baltuch GH, Farmer JP, Meagher-Villemure K, O'Gorman AM, Montes JL. Gangliogliomas presenting as a vascular lesion in a 10-year-old boy. J Neurosurg 1993; 79: 920-923.

15. Little NS, Morgan MK, Eckstein RP. Primary ependymoma of a cranial nerve. Case report. J Neurosurgery 1944; 81: 792-794.

16. Courville CB, Broussalian SL. Plastic ependymomas of the lateral recess. Report of eight verified cases. J Neurosurg 1961; 18 : 792-799.

17. Epstein BS, Epstein JA, Carras R. Extension of posterior fossa tumours, particularly intraventricular fourth ventricle tumours, into the upper cervical spinal canal. Am J Radiol 1970; 110:31-38.

18. Cosgrove GR, Villemure JG, Robitaille Y, Melanson D. Extra-axial ependymoma of the posterior fossa. Surg Neurol 1985; 24: 433436.

19. Morantz RA, Kepes JJ, Batnitzky S, Masterson BJ. Extraspinal ependymomas. Report of three cases. J Neurosurg 1979; 51: 383-391. 
20. Wolff M, Santiago H, Duby MM. Delayed distant metastasis from a subcutaneous sacrococcygeal ependymoma. Case report with tissue culture, ultrastructural observations, and review of the literature. Cancer 1972; 30: 10146-10167.

21. Yu YL, Crockard HA, Smith JJ, Harries BJ. Extraspinal ependymoma at the cervicothoracic junction. Surg Neurol 1982; 17: 160-162.

22. Moser FC, Tuvia J, LaSalle P, Llana J. Ependymoma of the spinal nerve root: case report. Neurosurgery 1992; 962-964.

23. Friede RL, Yasargin MG. Supratentorial intracerebral epithelial (ependymal) cysts: review, case reports, and fine structure. J Neurol Neurosurg Psychiatry 1977; 40: 127-137.

24. Ghatak NR, Hirano A, Kasoff SS, Zimmerman HM. Fine structure of an intracerebral epithelial cyst. J Neurosurg 1974; 41: 75-82.
25. Ho KL, Chason JL. A glioependymal cyst of the cerebellopontine angle. Immunohistochemical and ultrastructural studies. Acta Neuropathol (Berl) 1987; 74: 382-388.

26. Jakubiak P, Dunsmore RH, Beckett RS. Supratentorial brain cysts. J Neurosurg 1968; 28: 129-136.

27. Schelper RL, Ramzy I, Durr N. Ependymal cyst of the subarichnoid space. Cytologic diagnosis and developmental considerations. Acta Cytologica 1985; 29: 44-48.

28. Tandon PN, Roy S, Elvidge A. Subarachnoid ependymal cyst. Report of two cases. J Neurosurg 1972; 37: 741-745.

29. Cooper IS, Kernohan JW. Heterotopic glial nests in the subarachnoid space: histopathologic characteristics, mode of origin, and relation to meningeal gliomas. J Neuropathol Exp Neurol 1951; 10: 16-29. 